\title{
Elemental Analysis of Galium incanum SM subsp Centrale Ehrend by X-ray Fluorescence Spectroscopy
}

\author{
Hüsniye Kayalar ${ }^{1^{*}}$, Cenk Durmuşkahya ${ }^{2}$ and Zehra Sinem Hortooğlu ${ }^{3}$ \\ ${ }^{1}$ Ege University, Faculty of Pharmacy, Department of Pharmacognosy, Bornova, Izmir, ${ }^{2}$ Celal Bayar University, Faculty of \\ Education, School of Applied Science, Demirci, Manisa, ${ }^{3}$ izmir Institute of Technology, Center for Materials Research, Urla, \\ izmir, Turkey
}

*For correspondence: Email: husniyekayalar@gmail.com; Tel: +905543986021

Received: 4 December 2012

Revised accepted: 14 October 2013

\begin{abstract}
Purpose: To evaluate the content of trace elements in Galium incanum SM. subsp. centrale Ehrend. Methods: The air-dried aerial parts of the plant material were used and its water extract $(2 \% \mathrm{w} / \mathrm{v}$ infusion) was analysed for trace elements using $x$-ray fluorescence (XRF) spectrometry.

Results: The aqueous extract depicted significant concentrations of macro- and micro-nutrients with heavy metal and metal oxide content of $4.07-6.02$ and $3.19-4.01 \%$ for powdered plant material and water extract, respectively. The contents of Ca (22840 ppm) and K (8204 ppm) were the highest among all the elements while $\mathrm{Zn}(45.9 \mathrm{ppm})$ and $\mathrm{Fe}(328 \mathrm{ppm})$ were also detected in significant amounts. Zn, $\mathrm{Mn}$ and $\mathrm{Cu}$ showed the highest content while those of $\mathrm{Mg}, \mathrm{Al}, \mathrm{K}, \mathrm{Ca}, \mathrm{Fe}$ and $\mathrm{P}$ lowest in the water extract.

Conclusion: The presence of significant levels of $\mathrm{Ca}, \mathrm{K}, \mathrm{Na}, \mathrm{Fe}, \mathrm{Zn}, \mathrm{Mg}, \mathrm{Mn}$ and $\mathrm{Cu}$ in $\mathrm{G}$. incanum subsp. centrale showed that this plant has notable nutrient elements. The traditional use of Gallium species as a diuretic may be attributed to its rich content of potassium.
\end{abstract}

Keywords: Rubiaceae, Galium incanum, Trace elements, Macronutrients, Micronutrients, X-ray fluorescence.

Tropical Journal of Pharmaceutical Research is indexed by Science Citation Index (SciSearch), Scopus, International Pharmaceutical Abstract, Chemical Abstracts, Embase, Index Copernicus, EBSCO, African Index Medicus, JournalSeek, Journal Citation Reports/Science Edition, Directory of Open Access Journals (DOAJ), African Journal Online, Bioline International, Open-J-Gate and Pharmacy Abstracts

\section{INTRODUCTION}

Rubiaceae, comprising 640 genera and over 10000 species in about 10 tribes distributed in the world, chiefly in tropical regions, form the fourth largest angiosperm family after Asteraceae, Orchidaceae and Leguminosae [1]Galium with 400 species distributed in both temperate and tropical regions is one of the largest genera of Rubiaceae [2]. Galium is represented in Turkey by 101 species [3]. These species are used to coagulate milk because of an enzyme in their chemical composition [4]. Galium aparine L., G. cruciata ( L.) Scop. and G. verum L. are used as diuretic, chloretics, against diarrhea and in the treatment of some stomach complaints, gout and epilepsy in folk medicine [5]. Iridoids, anthraquinones, triterpenic saponins, naphtalene derivatives, flavonoids, lignans and alkaloids have been reported from Galium species [6-9].

It is well known that many trace elements play a vital role in human health. Most of the studies on medicinal plants pertain to their secondary metabolites viz. glycosides, alkaloids, phenolic componds, essential oils and other active components and their biological effects. Considering the importance of trace elements 
and for adequate safety evaluation, the present study was aimed to determine the presence and quantity of metallic elements in G. incanum SM. subsp. centrale Ehrend., an endemic species known as "yoghurt herb" in Turkey.

\section{EXPERIMENTAL}

The aerial parts of Galium incanum subsp. centrale were collected in July 2012 from Ödemiş, Bozdağ, İzmir, Turkey. Plant material was identified by Dr. Cenk Durmuşkahya, Celal Bayar University, Faculty of Education, School of Applied Science, Demirci, Manisa. A voucher specimen (no. 1432) was deposited in the Herbarium of Pharmacognosy Department, Faculty of Pharmacy, Ege University, Izmir, Turkey.

The air-dried plant materials were cut into small pieces and ground into fine powder. The water extract of plant material was prepared as a 2 $\%$ w/v infusion and then filtered using Whatman filter paper no. 1 paper. The filtrate was concentrated using vacuum evaporator and kept at $-20{ }^{\circ} \mathrm{C}$ until use. The powdered plant material and water extract were analysed for content of trace elements by energy dispersive $\mathrm{x}$-ray fluorescence (XRF) spectroscopy. The elemental composition was determined by using SPECTRO IQ II (Ametek, Germany) with silicon drift detector SDD with resolution of $145 \mathrm{eV}$ at 10 000 pulses. The primary beam was polarized by Bragg crystal and Highly Ordered Pyrolytic Graphite - HOPG target. The samples (0.1 g) were measured during $300 \mathrm{~s}$ at voltage of $25 \mathrm{kV}$ and $50 \mathrm{kV}$, at current of 0.5 and $1.0 \mathrm{~mA}$ under helium atmosphere.

\section{RESULTS}

The elemental range for XRF spectroscopy is from sodium to uranium. Generally, it is difficult to quantify elements lighter than sodium. In this study, the concentrations of trace elements from sodium to uranium in the periodic table were determined in the water extract (WE) and powdered plant material (PM) of Galium incanum subsp. centrale by using XRF spectroscopy. The results showed various concentration of macroelements and microelements in the samples. An examination of the data from Table 1 shows that $\mathrm{PM}$ and $\mathrm{WE}$ contain $\mathrm{Na}, \mathrm{Mg}, \mathrm{Al}, \mathrm{Si}$, $\mathrm{S}, \mathrm{K}, \mathrm{Ca}, \mathrm{Fe}, \mathrm{Cl}, \mathrm{Mn}$ and $\mathrm{Zn}$ and their oxides in various proportions. The results indicate that heavy metal and metal oxide content was 4.07 6.02 and 3.19 - $4.01 \%$ for powdered plant material and water extract, respectively.

\section{DISCUSSION}

$\mathrm{XRF}$ technique is well suited for multielemental determinations in plant samples. The samples do not need any chemical treatment and any possible contamination is therefore avoided. $\mathrm{XRF}$ is one of the sensitive, rapid and simple analytical technique to study the essential element content of medicinal plants $[10,11]$.

Many trace elements play significant roles in various physiological and biochemical events. Excessive levels of these elements in medicinal plants could lead to toxicity. Food and Nutrition Board recommends calcium intake as 1000 $\mathrm{mg} /$ day wheras the recommended daily intake of sodium and potassium are $1500 \mathrm{mg} /$ day and 2300 - $3200 \mathrm{mg} /$ day, respectively [12]. Plants are important link in the transfer of trace elements from soil to humans [13]. Fruits and vegetables are safe and valuable sources of minerals [14]. In previous studies, medicinal plants are shown to posses some important elements which have both therapeutic and prophylactic properties [13-17]. In addition to expressing their nutrient contents as the uncombined elements, metals are also expressed as their oxides. Therefore, in this study, the oxide forms of elements in G. incanum subsp. centrale were also determined. The concentration of $\mathrm{Ca}$ was determined as 22840 and 2917 ppm for PM and WE, respectively. $\mathrm{CaO}$ was measured as 31950 and $4081 \mathrm{ppm}$ in PM and WE, respectively. Solubility depends on the form of metal (i.e., whether the metal exists in a free or complexed form). Metal transfer from herbs to final extract is both sample-dependent and solvent-dependent. This study was also aimed to investigate the metal content of the extract prepared from $G$. incanum subsp. centrale. The resulting metal concentrations in WE increased or decreased when compared with PM. For example, concentrations of $\mathrm{Zn}, \mathrm{Mn}$, and $\mathrm{Cu}$ increased whereas that of $\mathrm{Mg}, \mathrm{Al}, \mathrm{K}, \mathrm{Ca}$ and $P$ decreased in WE.

The role of inorganic elements in human metabolism has long been established. Macroand microelements influence many biochemical processes to maintain good health. Study of elements with respect to medicinal plants reveals that major and trace elements play significant roles in combatting diseases $[17,18]$. Some metals in health products are as a result of adulteration. Many herbs are metal accumulators and take up both essential and non-essential metals from soil and environment during the growth. Thus, knowledge of metal content is also essential to evaluating the quality of herbal products. 
Table 1: Metal and metal oxide content (ppm) of water extract (WE) and powdered drug (PM) of G.incanum subsp. Central

\begin{tabular}{|c|c|c|c|c|c|c|c|}
\hline $\mathbf{Z}$ & Symbol & Element & PM (ppm) & $\begin{array}{l}\text { WE } \\
\text { (ppm) }\end{array}$ & Symbol & PM (ppm) & WE (ppm) \\
\hline 11 & $\mathrm{Na}$ & Sodium & 788 & $<810$ & $\mathrm{Na}_{2} \mathrm{O}$ & 1060 & $<1100$ \\
\hline 12 & $\mathrm{Mg}$ & Magnesium & 1176 & 614 & $\mathrm{MgO}$ & 1950 & 1018 \\
\hline 13 & $\mathrm{Al}$ & Aluminum & 1026 & 371.9 & $\mathrm{Al}_{2} \mathrm{O}_{3}$ & 1939 & 703 \\
\hline 14 & $\mathrm{Si}$ & Silicon & 2616 & 566.1 & $\mathrm{SiO}_{2}$ & 5597 & 1211 \\
\hline 15 & $P$ & Phosphorus & 676.7 & 487.8 & $\mathrm{P}_{2} \mathrm{O}_{5}$ & 1551 & 1118 \\
\hline 16 & $S$ & Sulfur & 1659 & 1092 & $\mathrm{SO}_{3}$ & 4142 & 2726 \\
\hline 17 & $\mathrm{Cl}$ & Chlorine & 475.5 & 723.2 & $\mathrm{Cl}$ & 475.5 & 723.2 \\
\hline 19 & $\mathrm{~K}$ & Potassium & 8204 & 6664 & $\mathrm{~K}_{2} \mathrm{O}$ & 988.3 & 8028 \\
\hline 20 & $\mathrm{Ca}$ & Calcium & 22840 & 2917 & $\mathrm{CaO}$ & 31950 & 4081 \\
\hline 22 & $\mathrm{Ti}$ & Titanium & 82.3 & 15.2 & $\mathrm{TiO}_{2}$ & 137.3 & 25.4 \\
\hline 23 & $\mathrm{~V}$ & Vanadium & 11.1 & 7.9 & $\mathrm{~V}_{2} \mathrm{O}_{5}$ & 19.8 & 14.1 \\
\hline 24 & $\mathrm{Cr}$ & Chromium & $<5.1$ & $<5.1$ & $\mathrm{Cr}_{2} \mathrm{O}_{3}$ & $<7.4$ & $<7.4$ \\
\hline 25 & $\mathrm{Mn}$ & Manganese & 130.6 & 159.2 & $\mathrm{MnO}$ & 168.6 & 205.5 \\
\hline 26 & $\mathrm{Fe}$ & Iron & 328 & 53.7 & $\mathrm{Fe}_{2} \mathrm{O}_{3}$ & 468.9 & 76.8 \\
\hline 27 & Co & Cobalt & $<3$ & $<3$ & $\mathrm{CoO}$ & $<3.9$ & $<3.9$ \\
\hline 28 & $\mathrm{Ni}$ & Nickel & $<2$ & $<2.4$ & $\mathrm{NiO}$ & $<2.6$ & $<3.1$ \\
\hline 29 & $\mathrm{Cu}$ & Copper & 22.1 & 1066 & $\mathrm{CuO}$ & 27.7 & 1330 \\
\hline 30 & $\mathrm{Zn}$ & Zinc & 45.9 & 3481 & $\mathrm{ZnO}$ & 57.2 & 4333 \\
\hline 31 & $\mathrm{Ga}$ & Gallium & $<1$ & $<1$ & $\mathrm{Ga}$ & $<1$ & $<1$ \\
\hline 33 & As & Arsenic & $<1$ & $<1$ & $\mathrm{As}_{2} \mathrm{O} 3$ & $<1.3$ & $<1.3$ \\
\hline 34 & $\mathrm{Se}$ & Selenium & $<1$ & $<1$ & $\mathrm{Se}$ & $<1$ & $<1$ \\
\hline 35 & $\mathrm{Br}$ & Bromine & 6.6 & 460 & $\mathrm{Br}$ & 6.6 & 460 \\
\hline 37 & $\mathrm{Rb}$ & Rubidium & 6.4 & 206 & $\mathrm{Rb}_{2} \mathrm{O}$ & 6.9 & 22.6 \\
\hline 38 & $\mathrm{Sr}$ & Strontium & 23.1 & 707 & $\mathrm{SrO}$ & 27.3 & 83.6 \\
\hline 39 & $\mathrm{Y}$ & Yttrium & 1.2 & 272 & $\mathrm{Y}$ & 1.2 & 272 \\
\hline 40 & $\mathrm{Zr}$ & Zirconium & $<510$ & $<510$ & $\mathrm{ZrO}_{2}$ & $<680$ & $<680$ \\
\hline 42 & Mo & Molybdenum & 12.8 & 1247 & Mo & 12.8 & 1247 \\
\hline 47 & $\mathrm{Ag}$ & Silver & 32 & 3030 & $\mathrm{Ag}$ & 32 & 3030 \\
\hline 48 & $\mathrm{Cd}$ & Cadmium & $<5.6$ & $<5.1$ & $\mathrm{Cd}$ & $<5.6$ & $<5.1$ \\
\hline 50 & Sn & Tin & $<6.1$ & $<6.1$ & $\mathrm{SnO}_{2}$ & $<7.7$ & $<7.7$ \\
\hline 51 & $\mathrm{Sb}$ & Antimony & $<6.1$ & $<6.1$ & $\mathrm{Sb}_{2} \mathrm{O}_{5}$ & $<8$ & $<8$ \\
\hline 53 & I & lodine & $<7.1$ & $<7.1$ & I & $<7.1$ & $<7.1$ \\
\hline 55 & Cs & Cesium & $<8.1$ & $<8.1$ & Cs & $<8.1$ & $<8.1$ \\
\hline 56 & $\mathrm{Ba}$ & Barium & $<68$ & $<4700$ & $\mathrm{Ba}$ & $<68$ & $<4700$ \\
\hline 57 & La & Lanthanum & $<10$ & $<10$ & $\mathrm{La}$ & $<10$ & $<10$ \\
\hline 74 & W & Tungsten & $<2$ & 142.3 & $\mathrm{WO}_{3}$ & $<2.5$ & 179.4 \\
\hline 80 & $\mathrm{Hg}$ & Mercury & $<\overline{2}$ & $<2$ & $\mathrm{Hg}$ & $<2$ & $<2$ \\
\hline 82 & $\mathrm{~Pb}$ & Lead & $<2.9$ & $<150$ & $\mathrm{PbO}$ & $<3.2$ & $<160$ \\
\hline 83 & $\mathrm{Bi}$ & Bismuth & $<2$ & $<2$ & $\mathrm{Bi}$ & $<2$ & $<2$ \\
\hline 90 & Th & Thorium & $<2$ & 770 & Th & $<2$ & 770 \\
\hline 92 & $\mathrm{U}$ & Uranium & $<3$ & 487 & U & $<3$ & 487 \\
\hline
\end{tabular}

Ca deficiency produce skeletal muscle spasms and abnormality in heart beat. It is also responsible for keeping bones strong and reducing the risk of osteoporosis [19]. Based on our results, $G$. incanum subsp. centrale is a rich source of dietary calcium.

$\mathrm{K}$ maintains cardiac rhythm and helps in reducing hypertension. Deficiency or excess of $\mathrm{K}$ can affect human health [20]. Dandelion (Taraxacum officinale F. H. Wigg) is a significant source of potassium and other minerals [21]. Reported K levels have ranged from 23.3 to 59.9 $\mathrm{mg} / \mathrm{g}$ of dried leaves [22,23]. Dandelion has been extensively employed as diuretic in traditional folk medicine and in modern phytotherapy in Europe. Additionally the
Comission E approves dandelion as diuretic due to its rich content of potassium [24]. The average concentration of potassium was 8204 and 6664 ppm for PM and WE. The use of Gallium species as diuretics may be attributed to rich content of potassium.

The depletion of sodium is characterized by hair loss, hypotension, mood changes and muscle cramps [25]. Mineral and heavy metals in some medicinal plants collected from local market were analysed and high levels of sodium were reported for dried leaves of Mentha spicata $L$. (808 ppm), Trigonella foenum-graceum L. (799 ppm) and Coriandrum sativum L. (813 ppm) [26]. The amount of $\mathrm{Na}$ was found as $788 \mathrm{ppm}$ in 
powdered aerial parts of $G$. incanum subsp. centrale.

Magnesium protects against diabetes and reduce blood pressure. In the body, magnesium supply is located in the bones together with calcium and phosphorous. Magnesium is also involved in insulin sensitivity and protein and nucleic acid synthesis. Phosphorous also plays important roles in every chemical reaction within the body. It forms calcium phosphate in the bones and teeth [27]. Significant concentrations of magnesium (1176 - 614 ppm) and phosphorous (676.7 - $487.8 \mathrm{ppm}$ ) were recorded for PM and WE.

Manganese is an essential metallic element for both plants and animals. It helps to asist the body in metabolizing protein and carbohydrates especially in treating diabetes. It plays a pivotal role in the normal growth, skeleton formation and reproductive function [28]. The average concentration in PM and WE was 130.6 and 159.2 ppm.

In a previous study, out of 24 investigated species, $\mathrm{Na}, \mathrm{K}, \mathrm{Ca}, \mathrm{Mg}$ and $\mathrm{Fe}$ levels for Taraxacum officinale were reported as 740,180 , 106, 6.4 and 29 ppm, respectively. The blood purifying effect of $T$. officinale was attributed to the presence of high iron content [29]. Spondias mombin L. and Vernonia amygdalina Delile are reported to be good antianaemic and antidiabetic agents because of high contents of iron and chromium. The copper contents were low with 13 $\mathrm{mg} / \mathrm{kg}$ in Spondias mombin and $11 \mathrm{mg} / \mathrm{kg}$ in Vernonia amygdalina [30]. The systemic decrease in $\mathrm{Cu}$ levels causes iron deficiency therefore it is antianaemic and essential for the formation of iron and haemoglobin [31]. Iron and copper content was determined as 328 22.1ppm and 53.7-1066 ppm in PM and WE respectively.

The leaves of Mentha spicata L. have been shown to be a rich source of zinc $(49.76 \mathrm{mg} / \mathrm{kg})$ [26]. Zinc is an essential metal for the normal functioning of various enzymes. $\mathrm{Zn}$ deficiency can lead to loss of appetite, growth retardation, weakness and even stagnation of sexual growth. Zinc has been reported for beneficial effects on vision, hair loss and increased milk production by pregnant women [32]. G. incanum subsp. centrale was shown to be rich source of $\mathrm{Zn}$.

The presence of high element concentrations gives a new sight into its potential use to compensate for element deficiencies in both man and animals as well as medicinal plants. Researchers are trying to link the contents of the trace elements and medicinal values of the plants. From XRF analysis results, it is obvious that $G$. incanum subsp. centrale accumulates essential elements in significant concentrations.

\section{CONCLUSION}

The levels of $\mathrm{Ca}, \mathrm{K}, \mathrm{Na}, \mathrm{Fe}, \mathrm{Zn}, \mathrm{Mg}, \mathrm{Mn}$ and $\mathrm{Cu}$ in $G$. incanum subsp. centrale indicate that the plant is a notable source of nutrient elements with potential therapeutic benefits. Chemical constituents of Galium species have been published previously. To the best of our knowledge, there is no scientific report on the mineral content of this genus. The water extract prepared from the plant material accumulated various elements in higher levels than the plant material itself. It is, therefore, important for safety reasons that evaluation of both the plant material itself and its water extract are carried out. The data obtained from this study lends some support for the use of the plant in traditional medicine in Turkey. The results also suggest that the plant material may be useful in the formulation nutritional and/or therapeutic products.

\section{ACKNOWLEDGEMENT}

The authors are thankful to Iyte-Mam (IztechCMR, Izmir, Turkey)members for their assistance in XRF measurements.

\section{REFERENCES}

1. Delprete PG, Choze $R$, Silva $R A$, Dufrayer $C R$. Chemotaxonomy and macroclassification of Rubiaceae. Scripta Botan Belg, 2006; 40: 28

2. Willis JC. A Dictionary of the Flowering Plants and Ferns. 8th edn. Cambridge University Press, Cambridge, UK; 1985.

3. Özhatay N. Galium L. In: Guner, A, Özhatay, N, Başer KHC. editors. Flora of Turkey and the East Eagean Islands, 11, 2000; pp 218-219.

4. Ergun F, Deliorman D, Velioğlu A, Şener B, Bozok C. Antimicrobial activity of Galium species. J Fac Pharm Gazi, 1999; 16: 7-11.

5. Baytop T. Therapy with Medicinal Plants in Turkey (Past and Present), Istanbul University Publications, No: 3255, Istanbul, 1984; pp 419.

6. Güvenalp Z, Kılıç N, Kazaz C, Kaya Y, Demirezer LÖ. Chemical constituents of Galium tortumense. Turk J Chem, 2006; 30: 515-523.

7. Mitova M, Anchev ME, Handjieva NV. Iridoid patterns in Galium L. and some phylogenetic considerations. Z. Naturforsch C 2002; 57 (3-4) : 226-234.

8. Demirezer LÖ, Gürbüz $F$, Güvenalp $Z$, Ströch $K$, Zeeck A. Iridoids, flavonoids and monoterpene glycosides from Galium verum subsp. verum. Turk $\mathrm{J}$ Chem 2006; 30: 525-534.

9. De Rosa S, Mitova M, Handjieva N, Popov S, Anchev $M$. Triterpene saponins with taxonomic significance and iridoid glucosides from Galium rivale. Phytochemistry 2000; 54: 751-756.

10. Queralt I, Ovejero $M$, Carvalho ML, Marques AF, Liabres JM. Quantitative determination of essential and trace element content of medicinal plants and 
their infusions by XRF and ICP techniques. $X$ Ray Spectrom 2005; 34: 213-217.

11. Shendkar $C D$, Chandrachood $P S$, Pawar $A B$, Lavate $S M$, deshpande NR. Quantitative estimation of macro, micronutrients and trace elements by $X$-ray fluorescence spectroscopy (XRF) from Achyranthes aspera Linn. Int $\mathrm{J}$ Chem Tech Res 2011; 3(2) : 610-613.

12. IOM. Dietary reference intakes: Elements. Available from: $h$ ttp://www.iom.edu.

13. Mark PE, Michael JB, Jianwei WH. Plants as source of concentrated mineral nutritional supplements. Food Chem 2000; 77: 181-188.

14. Haq F, Ullah E. Comparative determination of trace elements from Allium sativum, Rheum australe and Terminalia chebula by atomic absorption spectroscopy. IJB 2011; 1(5) : 77-82.

15. Harrington $K C$, Thatcher $A$ Kemp $P D$. Mineral composition and nutritive value of some common pasture weeds. N Z Plant Prot 2006; 59: 261-265.

16. Haq $F$, Rehman $A$, Ahmad $H$, lqbal $Z$, Ullah $R$. Elemental analysis of Paeonia emodi and Punica granatum by atomic absorption spectroscopy. Am J Biochem 2012; 2(4): 47-50.

17. Pandey MAB, Abidi S, Singh RP. Nutritional evaluation of leafy vegetables. Paratha. J Hum Ecol 2006; 19: 155-156.

18. Rajurkar NS, Damame MM. Elemental analysis of some herbal plants used in the treatment of cardiovascular diseases by NAA and AAS. J Radioanal Nucl Chem 1997; 219(1): 77-80.

19. Khan $K Y$, Khan MA, Niamat $R$, Munir $M$, Fazal $H$, Mazari P, Seema N, Bashir T, Kanwal A, Ahmed $S N$. Element content analysis of plants of genus Ficus using atomic absorption spectrometer. Afr J Pharm Pharmacol 2011; 5 (3) : 317-321.

20. Ekinci N, Ekinci R, Polat R, Budak G. Analysis of trace elements in medicinal plants with energy dispersive X-ray fluorescence. J Radional Nucl Chem 2004; 260: 127-131.

21. U.S. Department of Agriculture (USDA) Agricultural Research Service. Release 19. USDA national nutrient database for standard reference.
22. Rozyeki VR, Baigorria CM, Freyre M. Nutrient content in vegetable species from the Argentino Chaco. Arch Latinoam Nutr 1997; 47: 265-270.

23. Müller HL, Kirchgessner M. Quantity and trace element contents of dandelions and their dependence on growth. Das Wirtshaftseigene Futter, 1972; 18. 213-221.

24. Blumenthal M, Busse WR. Federal Institute for drugs and medical devices (Germany). The complete commission E monographs, Therapeutic Guide to Herbal Medicines. Austin: American Botanical Council; Integrative Medicine Communications, 1998.

25. Morris MJ, Na SE, Johnson AK. Salt craving: The psychobiology of pathogenic sodium intake. Physiol Behav 2008; 94: 709-721.

26. Subramanian $R$, Gayathri $S$, Rathnavel C, Raj V. Analysis of mineral and heavy metals in some medicinal plants collected from local market. Asian Pac J Trop Biomed 2012; 74-78.

27. Shendkar $C D$, Chandrachood PS, Pawar AB, Lavate SM, Deshpande NR. Quantitative estimation of macro, micro nutrients and trace elements by $X$-ray fluorescence spectroscopy (XRF) from Achyranthes aspera Linn. Int $\mathrm{J}$ Chem Tech Res 2011; 3 (2) : 610-613.

28. Wang $D, D u X$, Zheng $W$. Alteration of saliva and serum concentrations of manganese, copper, zinc, cadmium, and lead among career welders. Toxicol Lett 2008; 176: 40-47.

29. Ata S, Farooq $F$, Shabnam J. Elemental profile of 24 common medicinal plants of Pakistan and its direct link with traditional uses. J Med Plant Res 2011; 5 (26): 6164-6168.

30. Ayoola PB, Adeye A, Onawumi OO. Trace elements and major minerals evaluation of Spondias mombin, Vernonia amygdalina and Momordica charantia leaves. Pak J Nutr 2010; 9(8) : 755-758.

31. Barreau C, Solomon P. The manual of natural living. 1st ed. Biddles Ltd, Guilford, Surrey; 1979; pp 98-101.

32. Saracoglu S, Tuzen M, Soylak M. Evaluation of trace element contents of dried apricot samples from Turkey. J Hazard Mater 2009; 156: 647-652. 